president's role to provide energy, imagination, and leadership to an organization, yet the responsibilities one has to one's own institution impose a finitude upon us all. The organization itself has to compensate for this, and President Farber expressed the need for cooperation and support from the committees and sections. He encouraged the committee and section chairs to do as much as possible, because it is through these groups that the association can design and implement meaningful programs. The thrust that is provided by the committees and sections is carried out by the executive secretary, and President Farber noted his having been impressed with the work of the executive secretary over the course of the past year.

\title{
ACRL Officers for 1978/79
}

Evan Ira Farber, head librarian at Earlham College (Lilly Library, Richmond, IN 47374), is the fortieth president of the Association of College and Research $\mathrm{Li}$ braries, a division of the American Library Association. During his term of office, Farber will preside over the ACRL Board of Directors and the ACRL Executive Committee. He will develop the plans for ACRL's major program meeting at the 1979 ALA Annual Conference in Dallas and will chair the ACRL Conference Program

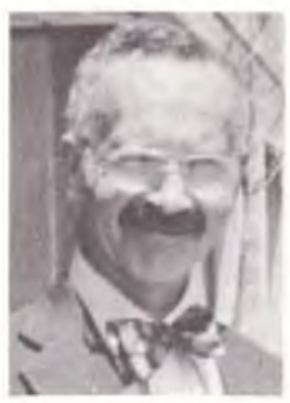

Evan Ira Farber
Planning Committee for that conference. The president serves as a member of all ACRL editorial boards and as an ex-officio member of all other units of the association.

As president of the division, Farber will represent ACRL on other ALA committees, including the ALA Dallas Conference Program Committee and the ALA Divisional Interests Special Committee. Farber also represents ACRL and ALA to other organizations, such as the American Council on Education.

In the past, Farber has served ACRL as chair of its College Libraries Section. He has served ALA as a member of the Library Administration Division's Buildings and Equipment Committee and the Non-Western Resources Committee. He was a Councilor for ALA from 1969 to 1971.

Le Moyne W. Anderson, director of libraries at Colorado State University (William E. Morgan Library, Fort Collins, CO 80523), is the newly elected vice-president/president-elect of the Association of College and Research Libraries. In the recent elections, Anderson received 1,349 votes, while Hendrik Edelman, newly appointed university librarian at Rutgers University, received 1,044 .
Anderson's prior service to ACRL has included a term on the Board of Directors, chair of the University Libraries Section, and membership on both the Goals, Priorities, and Structures and International Relations committees. In addition, he has served on the ALA Staff Organizations Round Table Steering Committee and the Library Research Round Table Nominations Committee.

As vice-president/president-elect of ACRL, Anderson will serve on the ACRL Board of Directors, the ACRL Executive Committee, and the ACRL Planning Committee. He will chair the ACRL Conference Program Planning Committee for the 1980 ALA Annual Conference in New York, and he will represent ACRL on the ALA Committee on Appointments, the ALA Budget Planning Assembly, and the ALA Conference Program Committee for the 1980 conference. At the close of the 1979 Annual Conference, he will become ACRL's forty-first president.

The results of the ACRL section elections follow. For each position, the elected candidate is listed first. The number of votes earned by each candidate is listed in parentheses.

\section{Agriculture and Biological SCIENCES Section}

Vice-Chair/Chair-Elect: Leila Moran, Chief, Reference Division, National Agricultural Library, Beltsville, MD 20705 (81); T. H. Milby, Science Librarian, Associate Professor of Bibliography, University of Oklahoma Library, Norman, OK 73019 (55).

Secretary (one-year term): Dolores B. Owen, Documents Librarian, University of Southwestern Louisiana Libraries, Lafayette, LA 70504 (73); Vladimir Micuda, Chief, Science and Technology Department, Pennsylvania State University Libraries, University Park, PA 16802 (61).

\section{ANTHROPOLOGY SECTION}

Vice-Chair/Chair-Elect: Anne K. Beaubien, Social Sciences Reference Librarian and Bibliographic Instructor, Hatcher Graduate Library, 
University of Michigan, Ann Arbor, MI 48109. Monica Reed, Research Librarian, Wenner-Gren Foundation Library, New York, NY 10021 (Withdrew).

Member-at-Large (two-year term): Barton M. Clark, Education and Social Science Librarian, University of Illinois, Urbana, IL 61801 (57); David R. McDonald, Social Science Bibliographer, Farrell Library, Kansas State University, Manhattan, KS 66506 (54).

\section{ART SECTION}

Vice-Chair/Chair-Elect: Gary R. Sipe, Director, Atlanta College of Art Library, Atlanta, GA 30309 (90); Joan Hugo, Art Librarian, Otis Art Institute, Los Angeles, CA 90057 (52).

\section{AsIan and African SEction}

Vice Chair/Chair-Elect: Yen-Tsai Feng, Librarian, Wellesley College, Wellesley, MA 02181 (78); -Alice N. Loranth, Department of Folklore, Orientalia and Chess, Cleveland Public Library, Cleveland, OH 44114 (46).

Member-at-Large (three-year term): Elizabeth Widenmann, Cataloger and African Bibliographer, Columbia University Libraries, New York, NY 10027 (74); E. Christian Filstrup, First Assistant, Oriental Division, New York Public Library, New York, NY 10018 (44).

\section{Bibliographic InStruction Section}

Chair: Sheila Laidlaw, Librarian, Sigmund Samuel Library, University of Toronto, Toronto, Canada M5S 1A5 (277); Pamela J. Cravey, Bibliographic Instruction Coordinator, Georgia State University, Atlanta, GA 30303 (186).

Vice-Chair/Chair-Elect: Sharon Hogan, Reference Librarian and Bibliographic Instructor, University of Michigan, Ann Arbor, MI 48109 (306); Brian T. Nielsen, Reference and Instruction Librarian, Undergraduate Library, University of North Carolina at Chapel Hill, Chapel Hill, NC 27514 (155).

Secretary (one-year term): Melissa M. Cain, Assistant Undergraduate Librarian, University of Illinois, Urbana, IL 61801 (237); Mignon Adams, Coordinator of Library Instruction, SUNYOswego, Oswego, NY 13126 (217).

Member-at-Large (one-year term): Louise P. Gerity, Bibliographic Instruction Librarian, Lewis and Clark College, Portland, OR 97219 (259); Glenda S. Neely, Reference Librarian, University of Louisville, Louisville, KY 40208 (188).

Member-at-Large (two-year term): Cleo Treadway, Director of Library Services, Tusculum College, Greenville, TN 37743 (228); Linda L. Lester, Public Services Librarian, Findlay College, Findlay, OH 45840 (216).

Member-at-Large (three-year term): Carla J. Stoffle, Assistant Director of the Library/ Learning Center, University of Wisconsin-
Parkside, Kenosha, WI 53141 (297): William W. Prince, Head, General Reference Division, Virginia Polytechnic Institute and State University, Blacksburg, VA 24061 (169).

\section{College Librarues Section}

Vice-Chair/Chair-Elect: Carla J. Stoffle, Assistant Director of the Library/Learning Center, University of Wisconsin-Parkside, Kenosha, WI 53141 (450); Norma N. Yueh, Director of Library Services, Ramapo College of New Jersey, Mahwah, NJ 07430 (237).

Secretary (one-year term): John P. Herling, Chief Librarian and Chairperson, Library Department, Brooklyn College, City University of New York, Brooklyn, NY 11210 (367); Robert R. Walsh, Library Planning Consultant, Jackson Heights, New York, NY 11372 (305).

\section{Community and Junior College Libraries SECTION}

Vice-Chair/Chair-Elect: James O. Wallace, Director of Learning Resources, San Antonio College Library, San Antonio, TX 78284 (139); Joseph F. Lindenfeld, Director of Library Services, Shelby State Community College, Memphis, TN 38104 (136).

Secretary (one-year term): MaryCraven Smith, Assistant Director, Division of Educational Resources, Department of Community Colleges, North Carolina State Board of Education, Raleigh, NC 27611 (165); Gorman L. Duffett, Coordinator Librarian/Professor, Learning Resources Center, Metropolitan Campus, Cuyahoga Community College, Cleveland, OH 44115 (105).

\section{Education and Behavioral Sciences Section}

Vice-Chair/Chair-Elect: Theodore C. Hines, Chairman, Library Science/Education Technology Division, School of Education, University of North Carolina, Greenboro, NC 27410 (153); Paul A. Perry, Librarian of the Faculty of Education, Monroe C. Gutman Library, Harvard Graduate School of Education, Cambridge, MA 02138 (118).

\section{Law and Polmtical Science Section}

Vice-Chair/Chair-Elect: Tillie Krieger, Director, Law Classification Project, University of Illinois, Champaign, IL 61820 (104); Mary Constance McCarthy, Assistant Head, Reference Department, Northwestern University Library, Evanston, IL 60201 (74).

Member-at-Large (one-year term): Lorraine E. Lester, Technical Services Librarian and Assistant Professor, Law School Library, University of New Mexico, Albuquerque, NM 87131 (97); Harold B. Shill, Chief Circulation Librarian and Adjunct Assistant Professor of Political Science, West Virginia University, Morgantown, WV 26506 (77). 


\section{RARE BOOKS AND \\ MANUSCRIPTS SECTION}

Vice-Chair/Chair-Elect: Peter E. Hanff, Coordinator, Technical Services, The Bancroft Library, University of California, Berkeley, CA 94720 (208); Richard G. Landon, Head, Thomas Fisher Rare Book Library, University of Toronto, Toronto, Ontario, Canada M5S 1 A5 (180).

Member-at-Large (three-year term): Dean H. Keller, Curator of Special Collections, Kent State University Libraries, Kent, OH 44242 (228); Donald Farren, Providence, RI 02906 (151).

\section{Slavic and East}

European SECTION

Vice-Chair/Chair-Elect: Edward Kasinec, Research Bibliographer and Librarian, Ukrainian Research Institute, Harvard University, Cambridge, MA 02138 (57); George V. Hodowanec,
Director, William Allen White Library, Emporia State University, Emporia, KS 66801 (31).

Secretary (three-year term): Kay L. Shaffer, Slavic Bibliographer/Cataloger, University Libraries, State University of New York at Albany, Albany, NY 12222 (57); Harold M. Leich, Slavic Acquisitions Librarian, University of Illinois at Urbana/Champaign, Urbana, IL 61801 (34).

Member-at-Large (one-year term): Murlin Croucher, Slavic Bibliographer, Wilson Library, University of North Carolina, Chapel Hill, NC $27514(84)$.

\section{UNIVERSITY LibRaRies SECTION}

Vice-Chair/Chair-Elect: Jean Boyer Hamlin, Librarian, Dana Library, Rutgers University, Newark, NJ 07102 (735); Rita L. Paddock, Head of Public Services, Harvard College Library, Cambridge, MA 02138 (538).

\section{Continuing Education-V}

\section{Philosophical Square One-and Holding}

Librarians have enthusiastically responded to the topic of continuing education with an outpouring of words and an overabundance of committees. Problem definition, a prerequisite to action, lags behind. Perhaps it will be useful to consider the ways in which four of the current $\mathrm{CE}$ controversies and dilemmas touch professionals working in academic libraries.

First, concern has been expressed that a voluntary recognition system for continuing education (such as the model being refined by CLENE) may lead to mandatory continuing education. If the mandate originates at the state level, the greatest effect would be on persons employed at state colleges and universities. However, specialized librarians (e.g., law, medicine) working in these same settings might seek recognition from a national or regional association related to their specialty. A more radical point of view is that many academic librarians are already faced with mandatory continuing education, as evidenced by the increasing number of college and university libraries that expect their professionals to have or to obtain a second master's degree.

Second, many people think that CE should be a factor in promotion, although we cannot decide which comes first-the employer should require it for promotion or the employee should expect that it be considered in promotion. Be that as it may, some college and university librarians will argue that they live in settings that have welldefined criteria for promotion and that continuing education is not one of them. Again, a slightly different point of view is that the tenure system will gradually be replaced by a contract system in which $\mathrm{CE}$ might well be an important consideration.

Third, many librarians complain that management is not interested in CE and staff develop-

\section{The Word from Colorado}

The editor of $C \& R L$ recently received this note from Ralph E. Ellsworth, director of libraries emeritus, University of Colorado, Boulder:

Several colleagues returning from the Chicago ALA Conference report that a "friend" is circulating rumors to the effect that I am: seriously ill, comatose, balmy in the grumpet, and no longer able to do consulting work. I hasten to state that I am happy, healthy, able to play daily snooker, go trout fishing and other activities common to 70 year-olds. Also, I am involved in various library building consulting activities. Having served on most of the ALA reorganization activities committees and on the intellectual freedom organization committee, I find much of the conference discussion redundant. When the dust settles, I'll start attending again. Sorry, "friend,"-Ralph E. Ellsworth. 